PYTHAGORAS: Jurnal Pendidikan Matematika

Volume 11 - Nomor 1, Juni 2016, (25-34)

Available online at: http://journal.uny.ac.id/index.php/pythagoras

\title{
Keefektifan Pembelajaran dengan Pendekatan CTL dan PBL Ditinjau dari Motivasi dan Prestasi Belajar Matematika Siswa
}

\author{
Husnul Laili \\ IAIN Mataram. Jalan Pendidikan, Dasan Agung Baru, Selaparang, Kota Mataram, 83125, Indonesia \\ Email: husnullaili29@gmail.com, Telp: +628175718276
}

Received: 15 ${ }^{\text {th }}$ June 2016; Revised: 20 ${ }^{\text {th }}$ August 2016; Accepted: $1^{\text {st }}$ September 2016

\begin{abstract}
Abstrak
Penelitian ini bertujuan untuk mendeskripsikan keefektifan pembelajaran dengan pendekatan Contextual Teaching and Learning (CTL) dan Problem Based Learning (PBL) ditinjau dari motivasi dan prestasi belajar matematika siswa, serta membandingkan keefektifan pembelajaran dengan pendekatan CTL dan PBL ditinjau dari motivasi dan prestasi belajar matematika siswa. Penelitian ini merupakan penelitian eksperimen semu, yang menggunakan dua kelompok eksperimen. Untuk mengetahui keefektifan pembelajaran dengan pendekatan CTL dan PBL digunakan uji one sample ttest pada taraf signifikansi 5\%. Untuk membandingkan keefektifan pembelajaran dengan pendekatan CTL dan PBL, data dianalisis secara multivariat menggunakan $T^{2}$ Hotelling dengan taraf signifikansi 5\% dan dianalisis lanjut menggunakan uji $t$ univariat dengan kriteria Bonferoni. Hasil penelitian menunjukkan bahwa pembelajaran dengan pendekatan CTL dan PBL efektif ditinjau dari motivasi dan prestasi belajar matematika siswa, dan pembelajaran dengan pendekatan PBL lebih efektif dibanding dengan pembelajaran dengan pendekatan CTL ditinjau dari prestasi belajar matematika siswa, tetapi pembelajaran dengan pendekatan PBL tidak lebih efektif dibanding dengan pembelajaran dengan pendekatan CTL ditinjau dari motivasi belajar matematika siswa.
\end{abstract}

Kata kunci: CTL, PBL, motivasi, prestasi belajar.

\section{The Effectiveness of the CTL and PBL Approaches Viewed from Students' Motivation and Achievement in Mathematics Learning}

\begin{abstract}
This study aimed to describe the effectiveness of the Contextual Teaching Learning (CTL) and Problem Based Learning (PBL) approaches viewed from students' motivation and achievement in mathematics learning, and to compare the effectiveness of the CTL and the PBL approach in mathematics learning viewed from students' motivation and achievement. This study was a quasiexperimental research and used two experimental groups. To find out the effectiveness of the CTL and $P B L$ approach in each variable, the data were analyzed using one-sample t-test what the significance level of 5\%. To compare the effectiveness of the CTL and PBL approaches, the data were analyzed using the multivariate T2 Hotelling with the significance level of $5 \%$ and followed up by the univariate analysis using the Bonferoni criterion. The results of the study show that the CTL and PBL approaches were effective viewed from students' motivation and achievement in mathematics learning and the PBL approach was more effective than CTL approach viewed from students' achievement in mathematics but the PBL approach is not more effective than CTL approach viewed from students' motivation in mathematics learning.
\end{abstract}

Keywords: CTL, PBL, motivation, learning achievement.

How to Cite: Laili, H. (2016). Keefektifan pembelajaran dengan pendekatan CTL dan PBL ditinjau dari motivasi dan prestasi belajar matematika. PYTHAGORAS: Jurnal Pendidikan Matematika, 11(1), 25-34. doi:http://dx.doi.org/10.21831/pg.v11i1.9679

Permalink/ DOI: http://dx.doi.org/10.21831/pg.v11i1.9679 


\section{PENDAHULUAN}

Pada hakikatnya, pendidikan dalam konteks pembangunan nasional mempunyai fungsi sebagai pemersatu bangsa, penyamaan kesempatan, dan pengembangan potensi diri. Pernyataan tersebut sejalan dengan Peraturan Pemerintah RI Nomor 19 Tahun 2005 tentang Standar Nasional Pendidikan yang mengemukakan bahwa pendidikan diharapkan dapat memperkuat keutuhan bangsa dan Negara Kesatuan Republik Indonesia (NKRI), memberi kesempatan yang sama bagi setiap warga negara untuk berpartisipasi dalam pembangunan, dan memungkinkan setiap warga negara untuk mengembangkan potensi yang dimiliki secara optimal.

Salah satu masalah pendidikan dewasa ini adalah lemahnya proses belajar mengajar. Dalam proses belajar mengajar dewasa ini, anak kurang didorong untuk mengembangkan kemampuan berpikir dalam pemecahan masalah matematika dan mengaplikasikannya dalam kehidupan sehari-hari. Menurut Sanjaya (2006, p.1) pembelajaran di kelas umumnya diarahkan kepada kemampuan anak untuk menghafal informasi. Otak anak dipaksa untuk mengingat dan menimbun berbagai informasi tanpa dituntut untuk memahami informasi yang diingatnya itu dan menghubungkannya dengan kehidupan sehari-hari. Hal ini yang menyebabkan kurangnya motivasi belajar siswa saat menerima pelajaran, yang akhirnya menyebabkan rendahnya prestasi belajar siswa.

Pentingnya motivasi belajar dikemukakan oleh Sardiman (2011, p.84) yang mengemukakan bahwa "motivation is an essential condition of learning". Hasil belajar akan optimal bila ada motivasi. Makin tinggi motivasi belajar siswa maka semakin berhasil pula tujuan pembelajaran yang diharapkan. Perlu ditegaskan bahwa motivasi bertalian dengan tujuan. Salah satu fungsi motivasi yaitu sebagai pendorong usaha dan pencapaian prestasi. Seseorang melakukan suatu usaha karena adanya motivasi. Adanya motivasi yang baik dalam belajar akan menunjukkan hasil yang baik.

Lebih mendalam membahas tentang motivasi, siswa diharapkan dapat membangkitkan dan mengembangkan motivasi belajar matematika yang ada pada diri mereka, sebagai modal utama untuk menumbuhkan kesenangan dan keinginan belajar matematika. Beberapa langkah yang dapat dilakukan oleh siswa untuk membangkitkan dan mengembangkan motivasi adalah (1) mengetahui manfaat matematika bagi kehidupan melalui contoh-contoh penerapan matematika yang relevan dengan dunia keseharian siswa, (2) menggunakan teknik, metode, serta pendekatan pembelajaran matematika yang tepat sesuai dengan karakteristik topik yang disajikan, dan (3) memanfaatkan teknik, metode, serta pendekatan yang bervariasi dalam pembelajaran matematika agar tidak monoton.

Mendukung uraian tentang motivasi pada paragraph sebelumnya, penerapan berbagai strategi pembelajaran sangat penting untuk dilakukan. Contextual Teaching and Learning (CTL) dan Problem Based Learning (PBL) dapat dijadikan sebagai salah satu upaya dalam menuntun siswa untuk bisa meningkatkan motivasi dan prestasi belajar khususnya dalam pembelajaran matematika, karena secara tidak langsung semua siswa dituntut untuk berpikir, sehingga mampu menyelesaikan masalah matematika dan mengaplikasikannya dalam kehidupan sehari-hari. Selain itu, CTL mengharuskan siswa untuk menemukan makna dalam kehidupan mereka. CTL menurut Hudson \& Dennis (1983, p.1) adalah konsep pembelajaran yang membantu guru mengaitkan isi mata pelajaran dengan situasi dunia nyata, dan memotivasi siswa untuk membuat hubungan antara pengetahuan dan aplikasinya untuk kehidupan mereka sebagai anggota keluarga, masyarakat, pekerja dan melakukan kerja keras yang membutuhkan pembelajaran. Pembelajaran dengan pendekatan kontekstual merupakan pembelajaran yang diorientasikan pada proses pengalaman langsung siswa, sehingga dalam pembelajaran siswa tidak hanya menerima pembelajaran tetapi proses mencari dan menemukan sendiri, siswa dalam pembelajaran jenis ini dipandang sebagai individu yang berkembang. Kemampuan belajar akan ditentukan oleh tingkat perkembangan dan pengalaman belajar mereka. Dengan demikian, peran guru tidak lagi sebagai instruktur, melainkan sebagai pembimbing siswa agar mereka dapat belajar sesuai dengan kemampuannya. Senada dengan pendapat tersebut, CORD (1999, p.11) mengemukakan bahwa pembelajaran CTL hanya terjadi ketika siswa/pembelajar memproses informasi baru atau pengetahuan sehingga dapat diterima oleh akal dalam bingkai acuan mereka sendiri dimana batin mereka sendiri sebagai memori, pengalaman, dan respon. Pendekatan pembelajaran kontekstual mengasumsikan bahwa pemikiran secara alami akan mencari makna dalam konteks yang dipelajari dan mencari hubungan yang sesuai, sehingga dapat memberikan manfaat dalam pembelajaran. 
Membahas lebih mendalam tentang CTL, Rusman (2010, p.193) mengemukakan bahwa terdapat enam prinsip pembelajaran CTL yang harus dikembangkan oleh guru. Keenam prinsip pembelajaran tersebut adalah sebagai berikut.

Konstruktivisme

Konstruktivisme merupakan landasan pikiran filosofi dalam CTL yang menyatakan bahwa pengetahuan dibangun oleh manusia sedikit demi sedikit, yang hasilnya diperluas melalui konteks yang terbatas. Strategi pembelajaran siswa dalam CTL adalah menghubungkan antara setiap konsep dengan kenyataan. Hal tersebut merupakan unsur yang lebih diutamakan dari pada penekanan terhadap banyaknya pengetahuan yang harus diingat oleh siswa.

\section{Bertanya (Questioning)}

Penerapan unsur bertanya dalam CTL harus difasilitasi oleh guru. Kebiasaan siswa untuk bertanya akan mendorong peningkatan kualitas dan produktivitas siswa. Melalui bertanya, pembelajaran akan lebih hidup, proses dan hasil pembelajaran menjadi lebih luas dan mendalam, dan akan banyak ditemukan unsurunsur terkait yang sebelumnya tidak terpikirkan baik oleh guru maupun siswa.

\section{Masyarakat Belajar (Learning Community)}

Masyarakat belajar adalah pembiasaan terhadap siswa untuk melakukan kerja sama dan memanfaatkan sumber belajar dari teman-teman belajarnya. Dalam learning community, hasil pembelajaran diperoleh dari kerja sama dengan orang lain melalui berbagai pengalaman (sharing).

\section{Pemodelan (Modelling)}

Pemodelan adalah proses pembelajaran dengan memperagakan sesuatu sebagi contoh yang dapat ditiru oleh siswa. Tahap pembuatan model dapat dijadikan alternatif untuk mengembangkan pembelajaran agar siswa bisa memenuhi harapan siswa secara menyeluruh dan membantu mengatasi keterbatasan yang dimiliki oleh para guru.

\section{Refleksi (Reflection)}

Refleksi adalah cara berpikir tentang apa yang baru terjadi atau baru saja dipelajari. Dengan kata lain, refleksi adalah berpikir ke belakang tentang apa yang sudah dilakukan di masa lalu. Pada tahap refleksi, siswa diberi kesempatan untuk mencerna, menimbang, membandingkan, menghayati, dan melakukan diskusi dengan dirinya sendiri (learning to be).

\section{Penilaian Sebenarnya (Authentic Assessment)}

Tahap terakhir dari pembelajaran kontekstual adalah melakukan penilaian. Penilaian sebagai bagian integral dari pembelajaran memiliki fungsi yang amat menentukan untuk mendapatkan informasi kualitas proses dan hasil pembelajaran melalui penerapan CTL. Penilaian adalah proses pengumpulan berbagai data dan informasi yang bisa memberikan gambaran atau petunjuk terhadap pengalaman belajar siswa.

Selain itu, Johnson (2002, p.24), mengatakan bahwa sistem pembelajaran kontekstual mencakup delapan komponen, yaitu (1) making meaningful connections, yaitu pembelajaran ditujukan untuk dapat menghubungkan yang bermakna antara ilmu yang diperoleh dengan kehidupan sehari-hari, (2) doing significant work, yaitu dalam pembelajaran, kegiatan yang dilakukan adalah kegiatan yang berarti atau biasa terjadi dalam kehidupan, (3) self-regulated learning, yaitu siswa dapat mangatur diri sendiri untuk belajar dan mendapatkan pengalaman, (4) collaborations, yaitu siswa diajak untuk dapat saling bekerja sama dalam memecahkan suatu masalah dalam proses pembelajaran, (5) critical and creative thinking, yaitu siswa dilatih untuk dapat berpikir kritis dan kreatif dalam menghadapi suatu masalah, (6) nurturing the individual yaitu guru tidak hanya mentrasfer ilmu saja melainkan medidik, melatih, dan memperdulikan siswa dalam proses pembelajaran, (7) reaching high standards yaitu siswa dilatih untuk mencapai hasil yang maksimal dalam belajar, dan (8) using authentic assessment yaitu guru memberikan nilai berdasarkan kenyataan yang sebenarnya.

Berdasarkan uraian yang dijabarkan para beberapa paragraf sebelumnya, komponen pembelajaran kontekstual meliputi (1) membuat keterkaitan-keterkaitan yang bermakna, (2) melakukan pekerjaan yang berarti, (3) melakukan pembelajaran yang diatur sendiri, (4) melakukan kerjasama, (5) berpikir kritis dan kreatif, (6) membantu individu untuk tumbuh dan berkembang, (7) mencapai standar yang tinggi, (8) menggunakan dan penilaian autentik. Komponen dan prinsip tersebut tentunya secara tidak langsung akan berpengaruh terhadap prestasi belajar siswa. Hal ini sesuai dengan hasil penelitian Wijayanti \& Sugiman (2013) dan diperkuat hasil penelitian Putri \& Abadi (2014) bahwa penerapan CTL dalam pembelajaran 
matematika efektif ditinjau dari prestasi belajar matematika siswa. Selain itu, hasil penelitian Setiana \& Jailani (2013) menunjukkan bahwa prestasi dan minat belajar matematika siswa mengikuti pembelajaran dengan metode CTL termasuk baik.

Strategi pembelajaran yang selanjutnya adalah Problem Based Learning (PBL). Delisle (1997, p.6) mendefinisikan bahwa PBL merupakan metode yang dapat membantu siswa membangun pemikiran dan kemampuan memecahkan masalah. PBL juga memberdayakan siswa dengan kebebasan yang lebih besar sekaligus memberikan proses yang dapat digunakan oleh guru untuk membimbing dan mengarahkan siswa. Sedangkan Howard \& Kelson (Taufiq Amir, 2010, p.21) menyatakan bahwa PBL adalah kurikulum dan proses pembelajaran. Dalam pembelajaran PBL dirancang masalahmasalah yang menuntut siswa untuk mendapatkan pengetahuan yang penting, membuat para siswa mahir dalam memecahkan masalah, memiliki strategi belajar sendiri, serta memiliki kecakapan berpartisipasi dalam tim. Proses pembelajarannya menggunakan pendekatan yang sistemik untuk memecahkan masalah atau menghadapi tantangan yang nanti diperlukan dalam karier dan kehidupan sehari-hari.

Berdasarkan definisi-definisi pada paragraf sebelumnya, nampak bahwa pembelajaran dalam PBL berciri utama adanya masalah, sehingga pada awal pembelajaran, guru diharapkan memulai pelajaran dengan memberikan masalah-masalah. Masalah yang disajikan merupakan masalah yang berhubungan dengan dunia nyata. Semakin dekat dengan dunia nyata, akan semakin baik pengaruhnya pada pemahaman siswa. Dari masalah yang diberikan, siswa diharapkan dapat bekerja sama dalam kelompok, mencoba memecahkan masalah dengan kemampuan yang mereka miliki, dan sekaligus mencari informasi-informasi baru yang relevan untuk menemukan solusinya. Dengan adanya pembelajaran yang melibatkan siswa belajar secara aktif, secara tidak langsung guru mendorong motivasi belajar siswa untuk mencapai tujuan pembelajaran. Hal ini diperkuat oleh hasil penelitian Farhan \& Retnawati (2014) yang menunjukkan bahwa penerapan PBL dalam pembelajaran matematika efektif ditinjau dari motivasi dan prestasi belajar siswa. Mendukung uraian sebelumnya, peran guru dalam PBL adalah menyodorkan berbagai masalah autentik, memfasilitasi penyelidikan siswa, dan mendukung pembelajaran siswa (Arends, 2008, p.41).
Senada dengan uraian tentang PBL pada paragraf sebelumnya, Taufiq Amir (2010, p.24) menyatakan bahwa dalam proses pembelajaran PBL memiliki tujuh langkah, yaitu mengklarifikasi istilah dan konsep yang belum jelas, merumuskan masalah, menganalisis masalah, menata gagasan dan secara sistematis menganalisisnya dengan dalam, mencari informasi tambahan dari sumber yang lain (diluar diskusi kelompok), mensintesis (menggabungkan) dan menguji informasi baru, dan membuat laporan untuk guru. Dengan memperhatikan kegiatan pada setiap tujuh langkah proses PBL, para siswa menggunakan banyak waktunya untuk mendiskusikan masalah, merumuskan hipotesis, menentukan fakta yang relevan, mencari informasi, dan mendefinisikan isi pembelajaran itu sendiri. Tidak seperti pembelajaran konvensional, tujuan pembelajaran dalam PBL tidak ditetapkan dimuka akan tetapi setiap anggota kelompok akan bertanggung jawab untuk membangun isi-isu atau tujuan berdasarkan analisa kelompok tentang permasalahan yang diberikan. Hal inilah yang menyebabkan pembelajaran dengan PBL lebih efektif dibandingkan dengan pembelajaran konvensional, sebagaimana dinyatakan dalam hasil penelitian Farhan \& Retnawati (2014).

Berdasarkan uraian sebelumnya, peneliti mengangkat pembelajaran dengan pendekatan PBL dan CTL dengan harapan dapat meningkatkan motivasi belajar dan yang pada akhirnya bisa meningkatkan prestasi belajar matematika siswa. Atas dasar pemikiran tersebut, sangat penting bahwa seorang guru dapat memilih strategi pembelajaran yang efektif. Guru hendaknya lebih kreatif dalam menggunakan strategi pembelajaran. Salah satu strategi pembelajaran yang dapat dipilih guru dalam pembelajaran adalah CTL dan PBL. Akan tetapi tingkat keberhasilan strategi ini dalam pembelajaran matematika belum diketahui dengan pasti. Terkait dengan latar belakang terseut, penelitian ini bertujuan untuk mendeskripsikan keefektifan pembelajaran dengan pendekatan CTL dan PBL ditinjau dari motivasi dan prestasi belajar matematika, serta membandingkan keefektifan pembelajaran dengan pendekatan CTL dan PBL ditinjau dari motivasi dan prestasi belajar matematika siswa.

\section{METODE}

Penelitian ini menggunakan quasi experiment design. Peneliti menggunakan kelompokkelompok untuk perlakuan karena peneliti tidak dapat memilih individu-individu secara acak. 
Kelompok-kelompok yang diberikan perlakuan adalah siswa kelas VII yang ada di SMPN 2 Keruak Kabupaten Lombok Timur. Kelompok I, yaitu kelas $\mathrm{VII}_{5}$, diberi pembelajaran dengan pendekatan CTL dan kelompok II, yaitu kelas $\mathrm{VII}_{6}$, diberi pembelajaran dengan pendekatan PBL. Pada kedua kelompok tersebut dilakukan pre-test dan post-test. Sedangkan perangkat pembelajaran yang digunakan adalah Silabus, Rencana Proses Pembelajaran (RPP), Lembar Kegiatan Siswa (LKS), tes prestasi belajar, dan angket untuk mengukur motivasi belajar.

Dalam penelitian ini, data diperoleh langsung oleh peneliti dengan memberikan perlakuan kepada kedua kelas eksperimen. Teknik pengumpulan data dengan tes untuk mengukur prestasi belajar dan non tes untuk mengukur motivasi belajar siswa. Instrumen tes yang digunakan dalam penelitian ini harus dianalisis validitas dan reliabilitas terlebih dahulu. Validitas yang digunakan untuk memvalidasi instrumen yang diperlukan dalam penelitian ini adalah validitas isi (content validity) dan validitas konstruk (construct validity).

Validitas isi (content validity) instrumen mengacu pada sejauh mana butir instrumen mencakup keseluruhan situasi yang ingin diukur. Validitas isi instrumen tes dapat diketahui dari kesesuaian instrumen tes tersebut dengan SK dan KD, sedangkan untuk angket motivasi diketahui dari kesesuaian instrumen yang telah dikembangkan dengan kisi-kisinya. Setelah instrumen dikonstruksi, instrumen dikonsultasikan dengan ahli. Validitas oleh ahli ini bertujuan untuk memperoleh bukti validitas isi.

Jenis validitas kedua yang digunakan adalah validitas konstruk. Validitas konstruk (construct validity) mengacu pada sejauh mana suatu instrumen mengukur trait atau konstruk teoretik yang hendak diukur. Untuk memperoleh bukti validitas konstruk, khususnya untuk instrumen non tes (angket motivasi belajar siswa), dilakukan uji coba. Data yang diperoleh dari hasil uji coba tersebut dianalisis dengan Factor Analysis. Menurut Stevens (2009, p.345), jika banyaknya faktor telah ditentukan sebelumnya maka digunakan Confirmatory Factor Analysis (CFA).

Keefektifan model pembelajaran ditentukan berdasarkan kriteria ketuntasan belajar matematika (KKM) di SMP Negeri 2 Keruak Kabupaten Lombok Timur yaitu siswa dikatakan tuntas belajar apabila mencapai nilai minimal 65,00 untuk skala 0-100, maka kriteria pencapaian tujuan pembelajaran aspek prestasi matematika ditetapkan yaitu 65,00 dengan Ketuntasan Klasikal (KK) $75 \%$.

Kategori keefektifan model pembelajaran aspek afektif, yaitu motivasi belajar siswa terhadap matematika diperoleh dengan menggunakan instrumen non-tes yang ber-bentuk checklist dengan skala Likert. Data yang diperoleh digolongkan dalam kriteria yang terdapat pada Tabel 1.

Tabel 1. Kategori Motivasi Belajar Siswa

\begin{tabular}{cc}
\hline Interval skor & Kriteria \\
\hline $\mathrm{X}>\bar{x}_{\mathrm{i}}+1,5 \mathrm{SBi}$ & Sangat tinggi \\
$\bar{x}_{\mathrm{i}}+0,5 \mathrm{SBi}<\mathrm{X} \leq \bar{x}_{\mathrm{i}}+1,5 \mathrm{SBi}$ & Tinggi \\
$\bar{x}_{\mathrm{i}}-0,5 \mathrm{SBi}<\mathrm{X} \leq \bar{x}_{\mathrm{i}}+0,5 \mathrm{SBi}$ & Sedang \\
$\bar{x}_{\mathrm{i}}-1,5 \mathrm{SBi}<\mathrm{X} \leq \bar{x}_{\mathrm{i}}-0,5 \mathrm{SBi}$ & Rendah \\
$\mathrm{X} \leq \bar{x}_{\mathrm{i}}-1,5 \mathrm{SBi}$ & Sangat Rendah
\end{tabular}

Berdasarkan tabel konversi tersebut, pembelajaran dinyatakan efektif jika minimal 75\% siswa memiliki skor angket motivasi berada pada kriteria tinggi dan sangat tinggi. Selanjutnya dilakukan uji one sample t-test dengan menggunakan bantuan SPSS 16 for windows dengan tujuan untuk mengetahui keefektifan keseluruhan model pembelajaran ditinjau dari prestasi belajar dan motivasi belajar matematika siswa. Uji one sample t-test. Menurut Tatsuoka (1971, p.77), formula yang digunakan untuk one sample t-test adalah sebagai berikut.

$$
\mathrm{t}=\frac{\bar{x}-\mu_{o}}{\frac{s}{\sqrt{n}}}
$$

Keterangan:

$$
\begin{array}{ll}
\bar{x} & : \text { rata-rata sampel } \\
\mu_{o} & : \text { nilai yang dihipotesis kan } \\
S & : \text { standar deviasi sampel } \\
n & : \text { ukuran sampel }
\end{array}
$$

Berdasarkan formula tersebut, kriteria pengambilan keputusannya adalah $\mathrm{H}_{0}$ ditolak jika $t_{\text {hitung }} \geq \mathrm{t}_{(0,05 ; \mathrm{n}-1)}$ atau nilai signifikansi kurang dari 0,05 .

Selain menganalisis keefektifan keseluruhan model pembelajaran ditinjau dari prestasi belajar dan motivasi belajar matematika siswa, penelitian ini dilaksanakan juga untuk melakukan komparasi terhadap model pembelajaran yang diteliti. Sebelum melakukan komparasi terhadap kedua model tersebut, data yang diperoleh harus memenuhi uji prasyarat, yaitu uji normalitas dan homogenitas. 
Pengujian normalitas dalam penelitian ini menggunakan jarak mahalanobis dengan pemeriksaan multivariat normal (Johnson \& Wichern, 2007, p.183). Pengujian dilakukan dengan cara membuat $q-q$ plot dari $d_{i}^{2}$ dan qi. Tahapantahapan dalam pembuatan $q-q$ plot adalah sebagai berikut.

1. Menentukan nilai vektor rata-rata $\bar{x}$ dan invers dari matrik varians kovarians $S^{-1}$.

2. Menentukan nilai $d_{i}^{2}$ yang merupakan jarak mahalanobis setiap pengamatan dengan vektor rata-ratanya: $d_{i}^{2}=\left(X_{i}-\bar{X}\right) S^{-1}\left(X_{i}-\bar{X}\right)^{T}$ dengan $i=1$, $2, \ldots, n$.

3. Mengurutkan $d_{i}^{2}$ dari yang terkecil hingga terbesar, $d_{(1)}^{2}<d_{(2)}^{2}<\ldots<d_{(n)}^{2}$.

4. Menentukan nilai $q i$ yang didekati dengan $\chi_{p}^{2}\left(\frac{n-i+\frac{1}{2}}{n}\right)$, dengan $p$ adalah derajat kebebasan.

5. Buat scatter plot jarak mahalanobis dengan ordinat $d_{i}^{2}$ dan axis qi, yaitu ( $\left.\chi_{p}^{2}\left(\frac{n-i+\frac{1}{2}}{n}\right), d_{i}^{2}\right)$.

bila plot yang dibuat membentuk pola garis lurus, dapat dikatakan bahwa data berdistribusi normal multivariat. Sedangkan kelengkungan menunjukkan penyimpangan dari normalitas. Titik-titik amatan yang jauh dari garis menunjukkan jarak yang besar atau dapat dikatakan bahwa amatan tersebut merupakan outlier.

Uji prasyarat yang selanjutnya adalah uji homogenitas. Untuk uji homogenitas terhadap prestasi dan motivasi belajar siswa terhadap matematika secara bersama-sama menggunakan Uji Box's M. Jika angka signifikansi (probabilitas) yang di hasilkan baik secara bersama-sama maupun secara sendiri-sendiri lebih besar dari 0.05 , maka matriks varians-kovarians pada variabel dependen adalah homogen. Uji homogenitas menggunakan bantuan SPSS 16 for windows.
Setelah kedua asumsi dipenuhi, analisis selanjutnya yang dilakukan adalah uji multivariat yang digunakan oleh peneliti untuk menguji hipotesis. Stevens (2009, p.151) berpendapat bahwa uji multivariat menggunakan statistik $T^{2}$ Hotelling dengan formula sebagai berikut.

$$
T^{2}=\frac{n_{1} n_{2}}{n_{1}+n_{2}}\left(\overline{y_{1}}-\overline{y_{2}}\right) S^{-1}\left(\overline{y_{1}}-\overline{y_{2}}\right)
$$

\section{Keterangan:}

$$
\begin{array}{ll}
\mathrm{T}^{2} & \text { : Hotelling Trace } \\
\mathrm{n}_{1} & \text { : besar sampel dari kelompok PBL } \\
\mathrm{n}_{2} & \text { : besar sampel dari kelompok CTL } \\
\mathrm{y}_{1} & \text { : vektor rerata skor kelompok PBL } \\
\mathrm{y}_{2} & \text { : vektor rerata skor kelompok CTL } \\
\mathrm{S} & \text { : matriks disperse }
\end{array}
$$

Selanjutnya nilai $T^{2}$ ditransformasi untuk memperoleh nilai dari distribusi $F$ dengan menggunakan formula sebagai berikut dengan kriteria pengambilan kesimpulan adalah $\mathrm{H}_{0}$ ditolak bila $F_{\text {hitung }}>F_{\text {tabel }}\left(\mathrm{F}_{0,05, \mathrm{dk} 1, \mathrm{dk} 2}\right)$.

$$
F=\frac{n_{1}+n_{2}-p-1}{\left(n_{1}+n_{2}-2\right) p} T^{2}
$$

Uji lanjut yang dilakukan dalam penelitian ini adalah uji univariat. Menurut Stevens (2009, p147) uji $t$ univariat dapat dilakukan dengan Hotteling $T^{2}$ dengan Formula sebagai berikut dan kriteria keputusannya adalah adalah $\mathrm{H}_{0}$ ditolak jika $\mathrm{t}_{\text {hitung }} \geq \mathrm{t}_{(0,025 ; n 1+n 2-2)}$.

$$
t=\frac{\overline{x_{1}}-\overline{x_{2}}}{\sqrt{\frac{\left.\left(n_{1}-1\right) S_{1}^{2}+\left(n_{2}-1\right) S_{2}^{2}\right)}{n_{1}+n_{2}-2}\left(\frac{1}{n_{1}}+\frac{1}{n_{2}}\right)}}
$$

Keterangan:

$\overline{x_{1}} \quad$ : Nilai rata-rata kelompok 1

$\overline{x_{2}} \quad$ : Nilai rata-rata kelompok 2

$S_{1}^{2} \quad$ : varian sampel kelompok 1

$S_{2}^{2} \quad$ : varian sampel kelompok 2

$n$ : banyak anggota sampel.

\section{HASIL DAN PEMBAHASAN}

Data yang telah diperoleh peneliti kemudian dianalisis. Data tentang hasil tes prestasi belajar siswa dapat dilihat secara terperinci pada Tabel 2. 
Pythagoras, 11 (1), Juni 2016 - 31

Husnul Laili

Tabel 2. Prestasi Belajar Siswa

\begin{tabular}{lcccc}
\hline \multicolumn{1}{c}{ Deskripsi } & \multicolumn{2}{c}{ CTL } & \multicolumn{2}{c}{ PBL } \\
\cline { 2 - 5 } & Pretest & Posttest & Pretest & Posttest \\
\hline Rata-rata & 3,467 & 73,60 & 3,40 & 82,67 \\
Standar deviasi & 2,515 & 12,002 & 1,905 & 11,807 \\
Varians & 6,326 & 144,041 & 3,628 & 139,402 \\
Skor maksimum & 10 & 100 & 8 & 100 \\
Skor minimum & 0 & 60 & 0 & 60 \\
Ketuntasan & $0 \%$ & $80 \%$ & $0 \%$ & $96,67 \%$ \\
Peningkatan ketuntasan & & $80 \%$ & & $96,67 \%$ \\
\hline
\end{tabular}

Tabel 3. Motivasi Siswa Sebelum dan Setelah Treatment

\begin{tabular}{lcccc}
\hline \multicolumn{1}{c}{ Deskripsi } & \multicolumn{2}{c}{ CTL } & \multicolumn{2}{c}{ PBL } \\
\cline { 2 - 5 } & Sebelum & Setelah & Sebelum & Setelah \\
\hline Banyak siswa & 30 & 30 & 30 & 30 \\
Rata-rata & 51,83 & 63,73 & 51,70 & 66,57 \\
Standar deviasi & 4,03 & 5,80 & 4,11 & 5,25 \\
Varians & 16,21 & 33,59 & 16.91 & 27,4954 \\
Skor maksimum & 61 & 74 & 58 & 75 \\
Skor minimum & 46 & 52 & 45 & 57 \\
Ketuntasan & $56,67 \%$ & $100 \%$ & $66,67 \%$ & $100 \%$ \\
Peningkatan ketuntasan & \multicolumn{2}{c}{$43,33 \%$} & & $33,33 \%$ \\
\hline
\end{tabular}

Berdasarkan Tabel 2, peningkatan ketuntasan belajar untuk pembelajaran dengan pendekatan CTL $80 \%$, sedangkan peningkatan ketuntasan belajar untuk pembelajaran dengan pendekatan PBL 96,67\%. Hal ini menunjukkan bahwa terdapat perubahan yang sangat signifikan dilihat dari hasil sebelum dan setelah diberikan treatment.

Selain prestasi belajar, peneliti juga mengumpulkan data yang berkenaan denga motivasi belajar siswa pada saat sebelum dan sesudah perlakuan. Data tersebut secara terperinci dapat dilihat dalam Tabel 3. Dari Tabel 3, dapat diperoleh informasi bahwa terjadi peningkatan rata-rata skor motivasi untuk pembelajaran dengan pendekatan CTL, yaitu dari 51,83 menjadi 63,73 dan peningkatan nilai rata-rata untuk pembelajaran dengan pendekatan PBL, yaitu dari 51,70 menjadi 66,57 . Hal ini menunjukkan bahwa terdapat perubahan yang sangat signifikan dilihat dari hasil sebelum dan setelah diberikan treatment.

Sebelum data tersebut dianalisis uji multivariat dan uji univariat, uji normalitas dan uji homogenitas dilakukan terlebih dahulu untuk mengetahui karakteristik data. Hasil scater plot jarak mahalanobis uji normalitas populasi sebelum treatment untuk pembelajaran dengan pendekatan CTL dan PBL menunjukkan bahwa scater plot jarak mahalanobis cenderung membentuk garis lurus. Berdasarkan hasil scatter plot tersebut dapat dikatakan bahwa asumsi normal multivariat terpenuhi karena titik-titik amatan mengikuti arah garis lurus diagonal.

Selanjutnya data diuji kehomogenannya. Berdasarkan hasil analisis dengan Box's $M$ dengan bantuan SPSS, taraf signifikansi data awal yang diperoleh adalah 0,377 dan bernilai lebih dari 0,05 , sedangkan taraf signifikansi data akhir adalah 0,072 dan bernilai lebih dari 0,05. Kedua hasil perhitungan tersebut menunjukkan bahwa matrik varians-kovarians pembelajaran dengan pendekatan CTL dan PBL homogen.

Uji hipotesis dilaksanakan setelah data diketahui bedistribusi normal dan homogen. Uji hipotesis pertama, yaitu uji keefektifan dilakukan dengan uji one sample t-test. Hasil one sample t-test untuk prestasi belajar dengan pendekatan CTL diperoleh nilai $t_{\text {hitung }}$ sebesar 3,93, untuk variabel motivasi belajar siswa diperoleh nilai $t_{\text {hitung }}$ sebesar 12,01 . Kedua nilai $t_{\text {hitung }}$ ini menunjukkan bahwa hasil yang diperoleh signifikan karena nilai $t_{\text {hitung }}$ tersebut lebih besar dari $\mathrm{t}_{\text {tabel }}=1,699$. Dengan demikian, pembelajaran dengan CTL efektif ditinjau dari prestasi dan motivasi belajar siswa.

Pada pembelajaran PBL, variabel prestasi diperoleh nilai $t_{\text {hitung }}$ sebesar 8,18 dan untuk variabel motivasi belajar siswa diperoleh nilai $t_{\text {hitung }}$ sebesar 16,22. Kedua nilai $t_{\text {hitung }}$ ini menunjukkan bahwa hasil yang diperoleh signifikan karena nilai-nilai tersebut lebih besar dari $t_{\text {tabel }}=$ 1,699. Dengan demikian, sebagaimana pembelajran CTL, pembelajaran PBL juga efektif baik 
ditinjau dari prestasi belajar matematika dan motivasi belajar siswa.

Uji selanjutnya yang dilakukan oleh peneliti adalah uji multivariat. Uji multivariat menggunakan statistik $T^{2}$ Hotelling dengan bantuan program SPSS 16 for windows. Hasil perhitungan dengan bantuan SPSS menunjukkan $F$ hitung sebesar 4,885 dan nilai signifikansi yang diperoleh adalah 0,014 . Nilai signifikansi tersebut kurang dari 0,05 . Hal tersebut menunjukkan bahwa $\mathrm{H}_{0}$ ditolak. Dengan demikian dapat disimpulkan bahwa terdapat perbedaan keefektifan antara CTL dan PBL ditinjau dari prestasi dan motivasi belajar matematika siswa.

Uji lanjutan yang dilakukan oleh peneliti adalah uji univariat. Uji lanjutan tersebut dilakukan karena berdasarkan hasil uji hipotesis multivariat tahap pertama, terdapat perbedaan keefektifan pembelajaran dengan pendekatan CTL dan PBL ditinjau dari prestasi matematika dan motivasi belajar siswa. Hasil analisis terhadap perbedaan prestasi matematika kedua kelompok diperoleh $t_{\text {hitung }}$ sebesar 2,95, kemudian $\mathrm{t}_{\text {tabel }}$ sebesar 2,301 atau $\mathrm{t}_{\text {hitung }}=2,95>\mathrm{t}_{0,025,58}=$ 2,301, sehingga dapat disimpulkan $\mathrm{H}_{0}$ ditolak. Dengan kata lain model pembelajaran PBL lebih efektif dari pembelajaran CTL ditinjau dari prestasi belajar matematika. Perhitungan pada variabel motivasi belajar siswa, diperoleh $t_{\text {hitung }}$ sebesar 1,99. Nilai tersebut kemudian dibandingkan dengan $t_{\text {tabel }}$ sebesar 2,301. Berdasarkan nilai hitung tersebut, $\mathrm{t}_{\text {hitung }}=1,99<\mathrm{t}_{0,025,58}=$ 2,301 sehingga dapat disimpulkan $\mathrm{H}_{0}$ diterima. Dengan demikian model pembelajaran PBL tidak lebih efektif dari CTL ditinjau dari motivasi belajar siswa terhadap matematika.

Data hasil uji statistik menunjukkan bahwa rata-rata hasil angket motivasi dan tes prestasi belajar siswa sebeum dan setelah dilakukan treatment mengalami peningkatan. Dengan demikian terbukti bahwa pendapat Sardiman A.M. (2011, p.84) yang mengemukakan bahwa hasil belajar akan menjadi optimal jika terdapat motivasi. Pernyataan tersebut bermakna bahwa dengan meningkatnya motivasi belajar, akan meningkat pula prestasi belajar siswa. Dengan demikian dapat disimpulkan bahwa siswa yang memiliki motivasi tinggi dalam belajar memiliki prestasi belajar yang tinggi pula. Hal ini dapat dilihat pada perolehan hasil posttest siswa yang menggunakan pembelajaran dengan pendekatan PBL mampu memperoleh nilai rata-rata 82,67.

Berdasarkan kriteria ketuntasan yang telah ditetapkan dan setelah dilakukan uji statistik dengan uji one sample t-test, dapat diketahui bahwa pembelajran CTL efektif dalam meningkatkan prestasi dan motivasi belajar siswa pada pelajaran matematika. Hal tesebut senada dengan pendapat yang dikemukakan oleh Johnson (2002, p.25) yang menyatakan bahwa CTL bertujuan untuk membantu para siswa melihat makna di dalam materi akademik yang mereka pelajari dengan cara menghubungkan subjek-subjek akademik dengan konteks dalam kehidupan keseharian mereka, yaitu dengan konteks keadaan pribadi, sosial, dan budaya mereka. Hal ini juga tidak terlepas dari tujuan utama CTL yaitu membantu para siswa dengan cara yang tepat untuk mengaitkan makna pada pelajaran-pelajaran akademik mereka.

Mendukung hasil penelitian yang telah dilaksanakan, Taufiq Amir (2010, p.27) mengemukakan bahwa PBL dapat meningkat pemahaman siswa atas materi pelajaran, meningkatkan fokus pada pengetahuan yang relevan, mendorong untuk berpikir, membangun kerja tim, kepemimpinan, dan keterampilan sosial, membangun kecakapan siswa (life-long learning skills), dan memotivasi siswa. Hal inilah yang menyebabkan pembelajaran dengan pendekatan PBL efektif dalam meningkatkan prestasi dan motivasi belajar matematika siswa. Hal tersebut mendukung hasil penelitian yang telah dilakukan dalam penelitian ini. Dengan demikian dapat disimpulkan bahwa kedua model pembelajaran baik pembelajaran dengan CTL maupun PBL efektif ditinjau dari prestasi dan motivasi belajar siswa.

Berdasarkan hasil analisis multivariat, diperoleh nilai probabilitas lebih kecil dari taraf signifikansi. Dengan demikian, hipotesis awal $\left(\mathrm{H}_{0}\right)$ penelitian yang berbunyi tidak terdapat perbedaan prestasi dan motivasi belajar siswa terhadap matematika yang menggunakan pembelajaran dengan pendekatan CTL dan PBL ditolak. Dengan demikian dapat disimpulkan bahwa efek dari pembelajaran CTL dan PBL ditinjau dari prestasi dan motivasi belajar siswa berbeda. Berdasar adanya perbedaan secara simultan tersebut, analisis dilanjutkan dengan uji $t$ univariat untuk mengetahui apakah secara univariat juga mempunyai perbedaan yang signifikan ditinjau dari prestasi dan motivasi belajar siswa terhadap matematika. Berdasarkan hasil perhitungan, dapat disimpulkan bahwa pembelajaran dengan pendekatan PBL lebih efektif dibanding dengan pembelajaran dengan pendekatan CTL ditinjau dari prestasi belajar matematika siswa, tetapi pembelajaran dengan pen- 
dekatan PBL tidak lebih efektif dibanding dengan pembelajaran dengan pendekatan CTL ditinjau dari motivasi belajar matematika siswa.

\section{SIMPULAN DAN SARAN}

\section{Simpulan}

Berdasarkan hasil analisis data dan pembahasan, kesimpulan yang diperoleh dari penelitian ini adalah bahwa pembelajaran dengan pendekatan CTL dan PBL efektif ditinjau dari prestasi dan motivasi belajar siswa pada mata pelajaran matematika, dan pembelajaran dengan pendekatan PBL lebih efektif dibanding pembelajaran dengan pendekatan CTL ditinjau dari prestasi belajar, tetapi pembelajaran dengan pendekatan PBL tidak lebih efektif dibandingkan pembelajaran dengan pendekatan CTL ditinjau dari motivasi belajar matematika siswa.

\section{Saran}

Saran yang disampaikan oleh peneliti kepada pihak sekolah, terutama guru adalah hendaknya guru menerapkan berbagai metode pembelajaran yang memungkinkan siswa untuk berpartisipasi aktif dalam belajar ataupun berpusat pada siswa. Guru matematika sebaiknya dalam melaksanakan pembelajaran memilih metode pembelajaran yang tepat dan lebih bervariasi yang dapat memberikan hasil belajar yang lebih baik. Salah satunya yaitu dengan penerapan pembelajaran dengan pendekatan CTL atau PBL.

Saran selanjutnya yang disampaikan oleh peneliti adalah hendaknya penelitian selanjutnya memperluas materi yang akan digunakan dalam penelitian, sehingga memungkinkan generalisasi yang lebih luas serta melakukan pengembangan yang lebih mendalam khususnya mengenai instrumen motivasi belajar siswa dalam pembelajaran matematika, sehingga diperoleh instrumen pengukuran yang akurat.

\section{DAFTAR PUSTAKA}

Arends, I. R. (2008). Learning to teach. (Terjemahan Helly Prajitno Soetjipto \& Sri Mulyantini Soetjipto). New York: McGraw Hill Companies. (Buku asli diterbitkan tahun 2007)

CORD. (1999). Teaching mathematics contextually. Diakses pada tanggal 29 april 2013 dari http://www.cord.org/ uploadedfiles/Teaching_Math_Contextual ly.pdf.
Delisle, R. (1997). How to use problem-based learning in the classroom. Alexandria, VA. ASCD.

Depdiknas. (2005). Peraturan Pemerintah RI Nomor 19, Tahun 2005, Standar Nasional Pendidikan.

Farhan, M., \& Retnawati, H. (2014). Keefektifan PBL dan IBL ditinjau dari prestasi belajar, kemampuan representasi matematis, dan motivasi belajar. Jurnal Riset Pendidikan Matematika, 1(2), 227240. doi:http://dx.doi.org/10.21831/jrpm.v1i2. 2678

Hudson, C. C. \& Dennis, D. H. (1983). Addressing Accountability via Contextual Teaching and Learning. Diakses pada tanggal 30 April 2013 dari http://www.wtamu.edu/webres/File/Journals/MCJ/Volume2/addressing_acc ountability.pdf

Johnson, E. B. (2002). Contextual teaching and learning. Thousand Oaks, CA: Corwin Press,Inc.

Johnson, R. A., Wichern, D. W. (2007). Applied multivariate statistical analysis. Upper Saddle River, NJ: Pearson Education.

Putri, R., \& Abadi, A. (2014). Keefektifan pembelajaran matematika dengan pendekatan CTL dan problem posing ditinjau dari ketercapaian $\mathrm{SK} / \mathrm{KD}$ dan kemampuan koneksi matematik. PYTHAGORAS: Jurnal Pendidikan Matematika, $\quad 9(1), \quad 79-89$. doi:http://dx.doi.org/10.21831/pg.v9i1.90 70

Rusman. (2010). Model-model pembelajaran, mengembangkan profesionalisme guru edisi kedua. Jakarta: Raja Geafindo Persada.

Sanjaya, W. (2006). Strategi pembelajaran berorientasi standar proses pendidikan. Jakarta: Prenada Media Group.Sardiman. A. M. (2011). Interaksi dan motivasi belajar mengajar. Jakarta: Raja Grafindo Persada.

Setiana, D., \& Jailani, J. (2013). Komparasi metode CTL dan open-ended dengan gaya belajar ditinjau dari prestasi dan minat belajar. PYTHAGORAS: Jurnal Pendidikan Matematika, 8(2), 135-145. 
Pythagoras, 11 (1), Juni 2016 - 34

Husnul Laili

doi:http://dx.doi.org/10.21831/pg.v8i2.89 39

Taufiq Amir. (2010). Inovasi pendidikan melalui problem based learning. Jakarta: Prenada Media Group.

Wijayanti, T., \& Sugiman, S. (2013). Keefektifan pendekatan CTL dan problem solving ditinjau dari prestasi belajar matematika dan religiusitas siswa. PYTHAGORAS: Jurnal Pendidikan Matematika, $\quad 8(2), \quad 213-223$. doi:http://dx.doi.org/10.21831/pg.v8i2.89 51 